\title{
Rosiglitazone Rescues Memory Impairment in Alzheimer's Transgenic Mice: Mechanisms Involving a Reduced Amyloid and Tau Pathology
}

\author{
Luis Escribano', Ana-María Simón', Esther Gimeno', Mar Cuadrado-Tejedor', Rakel López de Maturana', \\ Ana García-Osta', Ana Ricobaraza', Alberto Pérez-Mediavilla', Joaquín Del Río' and Diana Frechilla*' \\ 'Division of Neurosciences, CIMA, University of Navarra, Pamplona, CIBERNED, Spain
}

\begin{abstract}
Clinical studies suggest that agonists at peroxisome proliferator-activated receptor gamma (PPAR $\gamma$ ) may exert beneficial effects in patients with mild-to-moderate Alzheimer's disease (AD), but the mechanism for the potential therapeutic interest of this class of drugs has not yet been elucidated. Here, in mice overexpressing mutant human amyloid precursor protein, we found that chronic treatment with rosiglitazone, a high-affinity agonist at PPAR $\gamma$, facilitated $\beta$-amyloid peptide $(A \beta)$ clearance. Rosiglitazone not only reduced $A \beta$ burden in the brain but, importantly, almost completely removed the abundant amyloid plaques observed in the hippocampus and entorhinal cortex of 13-month-old transgenic mice. In the hippocampus, neuropil threads containing phosphorylated tau, probably corresponding to dystrophic neurites, were also decreased by the drug. Rosiglitazone switched on the activated microglial phenotype, promoting its phagocytic ability, reducing the expression of proinflammatory markers and inducing factors for alternative differentiation. The decreased amyloid pathology may account for the reduction of p-tau-containing neuropil threads and for the rescue of impaired recognition and spatial memory in the transgenic mice. This study provides further insights into the mechanisms for the beneficial effect of rosiglitazone in AD patients.

Neuropsychopharmacology (2010) 35, I593-1604; doi: I0.1038/npp.2010.32; published online 24 March 2010
\end{abstract}

Keywords: Alzheimer's disease; amyloid; tau; PPAR $\gamma$; hippocampus; memory

\section{INTRODUCTION}

Alzheimer's disease (AD), the most common form of dementia in the elderly, is characterized by the deposition of extracellular neuritic plaques, mainly composed of fibrillar $\beta$-amyloid $(\mathrm{A} \beta)$ peptide, and the formation of intracellular tangles containing hyperphosphorylated tau (Selkoe, 2001). Other pathological features highly related to synaptic deficits include dystrophic neurites, closely associated with intracerebral amyloid deposits of $\mathrm{AD}$ patients and preferentially positive for phosphorylated forms of tau (Su et al, 1998). A $\beta$ peptide is derived from the sequential proteolytic cleavage of amyloid precursor protein (APP) by $\beta$-secretase and presenilin-dependent $\gamma$-secretase to yield $\mathrm{A} \beta$ (Bayer et al, 2001). According to the amyloid cascade hypothesis (Hardy and Selkoe, 2002), A $\beta$ is the starting point for a sequence of pathogenic events, such as tau hyperphosphorylation and neuroinflammation, that

*Correspondence: Dr D Frechilla, Division of Neurosciences, CIMA, University of Navarra, CIBERNED, Av. Pio XII 55, Pamplona 31008, Spain, Tel: + 3494819 4700, Fax: + 3494819 4715, E-mail: dfrech@unav.es

Received 14 October 2009; revised 16 February 2010; accepted 19 February 2010 contribute to synaptic dysfunction and ultimately causes dementia. Although controversial, reducing $\mathrm{A} \beta$ would consequently contribute to ameliorate $\mathrm{AD}$ symptoms.

The brain possesses robust intrinsic $\mathrm{A} \beta$ clearance mechanisms (Tanzi et al, 2004). A $\beta$ peptides are proteolytically degraded within the brain mainly by neprilysin (NEP) (Iwata et al, 2000) and insulin-degrading enzyme (IDE) (Kurochkin and Goto, 1994). It has been recently reported that ApoE facilitates the proteolytic clearance of soluble $\mathrm{A} \beta$ from the brain both within microglia by NEP and extracellularly by IDE, in a process dependent on ApoE isoform and its lipidation level, where the cholesterol transporter ABCA1 and the nuclear liver X receptors (LXR) have a major role (Jiang et al, 2008). Activated microglia secrete different proinflammatory factors, an effect particularly observed in close proximity to the amyloid plaques (Zipp and Aktas, 2006). However, activated microglia also express receptors that promote the clearance and phagocytosis of $\mathrm{A} \beta$, such as $\mathrm{CD} 36$ and receptor for advanced glycation endproducts (RAGE) (Yan et al, 1996; El Khoury et al, 1998), and may restrict amyloid plaque formation by phagocytosing $\mathrm{A} \beta$ (Simard et al, 2006). It seems that, as $\mathrm{AD}$ progresses, the phenotype of microglia changes and these cells become more proinflammatory and lose their 
$\mathrm{A} \beta$-clearing capabilities, resulting in reduced $\mathrm{A} \beta$ uptake and degradation.

In addition to aging, which is the most obvious risk factor for the disease, epidemiological studies indicate that type 2 diabetes is associated with an increased risk of $\mathrm{AD}$ (Biessels and Kappelle, 2005). The thiazolidinediones, widely used in the treatment of type 2 diabetes, act as agonists at the nuclear receptor peroxisome proliferatoractivated receptor gamma (PPAR $\gamma)$ (Lehmann et al, 1995), a ligand-inducible transcription factor that decreases insulin resistance and regulates lipid metabolism and inflammation. Although controversial (see ADAPT Research Group, 2008), epidemiological studies suggest that non-steroidal anti-inflammatory drugs (NSAID) may reduce AD risk by inhibiting inflammatory responses in the $\mathrm{AD}$ brain, an effect linked to the ability of these drugs to stimulate PPAR $\gamma$ (Lehmann et al, 1997; in T' Veld et al, 2001; Landreth and Heneka, 2001). On this basis, the effects of agonists at $\operatorname{PPAR} \gamma$ on the amyloid cascade have been studied in vitro (Camacho et al, 2004; D'abramo et al, 2005), and their efficacy in AD mouse models has been explored (Sundararajan et al, 2006). Clinical studies suggest beneficial effects of PPAR $\gamma$ agonists in patients with mild to moderate $A D$ (Watson et al, 2005; Risner et al, 2006), but the mechanism(s) for the potential therapeutic interest of PPAR $\gamma$ agonists in $\mathrm{AD}$ has not yet been elucidated. We here report that chronic treatment with rosiglitazone, a high-affinity PPAR $\gamma$ agonist, improves recognition and spatial memory in a mouse model of $\mathrm{AD}$ and reduces the amyloid and tau pathology.

\section{MATERIALS AND METHODS}

\section{Animals and Drug Treatments}

Transgenic mice overexpressing human amyloid precursor protein (hAPP) with the Swedish (K670N/M671L) and Indiana (V717F) familial $\mathrm{AD}$ mutations under control of the PDGF $\beta$-chain promoter were used (J20 line) (Mucke et al, 2000). The mice were on an inbred C57BL/6J genetic background. Animals were housed 4-5 per cage with free access to food and water, and maintained in a temperaturecontrolled environment on a $12 \mathrm{~h}$ light-dark cycle. All procedures were carried out in accordance with the European and Spanish regulations (86/609/CEE; RD1201/ 2005). This study was approved by the Ethical Committee of the University of Navarra (no. 076/06).

We treated 9-month-old transgenic mice by oral gavage with rosiglitazone maleate (Avandia, GSK, Brentford, UK) as a suspension in sterile water at a dose of $5 \mathrm{mg} / \mathrm{kg} /$ day or with vehicle ( $n=11-12$ animals per group). Only male mice were used in this work. Age-matched non-transgenic mice (Non-Tg) received the vehicle. In all cases, animals were killed $24 \mathrm{~h}$ after the last administration. The brains were removed and immediately frozen on dry ice before dissection. Some animals were perfused transcardially with paraformaldehyde for immunohistochemistry.

\section{Behavioral Procedures}

Animals underwent the object recognition test after 4 weeks of treatment. The apparatus for this test consisted of a dark open box $(50 \times 35 \times 50 \mathrm{~cm}$ high $)$, illuminated by a $60 \mathrm{~W}$ lamp suspended $120 \mathrm{~cm}$ above the box. The objects consisted of red rectangular prisms $(2 \times 2 \times 8 \mathrm{~cm}$ high $)$ and white pyramids $(5 \times 5 \times 5 \mathrm{~cm}$ high $)$. These objects could not be displaced by the mice. In the week preceding testing, the animals were handled daily and adapted to the room in which the behavioral procedures were being carried out. The test was carried out as described elsewhere (Schiapparelli et al, 2006). At $1 \mathrm{~h}$ before testing, the mice were allowed to explore the apparatus without objects for $5 \mathrm{~min}$. After habituation, two familiarization sessions were given ( $\mathrm{T} 1$ and T2 $10 \mathrm{~min}$ apart), in which the animals were left to explore for $10 \mathrm{~min}$ two identical objects (red prisms) that were placed in opposite sides of the apparatus $10 \mathrm{~cm}$ from the sidewall. The choice trial (T3), in which memory retention was tested, was given $24 \mathrm{~h}$ after T2. In this session, two objects were presented, one of the prisms was used in familiarization session (T1 and T2) and other was different in shape and color; therefore the mice were re-exposed to a familiar (F) and a new object (N). Exploration was defined as directing the nose to an object at a distance $\leqslant 2 \mathrm{~cm}$ and/or touching the object with the nose. To avoid the presence of olfactory trails, the apparatus and the objects were thoroughly cleaned with ethanol after each trial. The time spent by the animals in exploring each object was recorded manually by using a stopwatch. The reaction to a new object during T3 was measured by calculating the discrimination index (DI): time spent exploring the new object over total exploration time. Consequently, a ratio of 0.5 reflects equal exploration of the familiar and the new object, indicating no learning retention.

We also used the Morris water maze (MWM) test to evaluate the spatial memory function in response to treatment with rosiglitazone in J20 mice, as previously described (Westerman et al, 2002). Groups of animals underwent spatial reference learning in the MWM test after 4 and 16 weeks of treatment. The water maze was a circular pool (diameter $1.45 \mathrm{~m}$ ) filled with water maintained at $20^{\circ} \mathrm{C}$ and made opaque by the addition of powdered skim milk. Mice underwent visible-platform training for 3 consecutive days (eight trials per day) using a platform raised above the surface of the water. No visible cues were present during this phase. This was followed by the hiddenplatform training (with all visible cues present) during which mice were trained to locate a platform in the opposite quadrant and submerged $1 \mathrm{~cm}$ beneath the surface for 8 consecutive days (four trials per day). In both the visibleand hidden-platform versions, mice were randomly placed in selected locations, facing toward the wall of the pool to eliminate the potentially confounding contribution of extramaze spatial cues. Each trial was terminated when the mouse reached the platform or after $60 \mathrm{~s}$, whichever came first. Mice failing to reach the platform were guided onto it. After each hidden-platform trial, mice remained on the platform for $20 \mathrm{~s}$. At $20 \mathrm{~h}$ after the 12th, 24th, and 32nd trials, all mice were subjected to a probe trial in which they swam for $60 \mathrm{~s}$ in the pool with no platform. Mice were monitored by a camera mounted in the ceiling directly above the pool, and all trials were recorded using an HVS water maze program for subsequent analysis of escape latencies, swimming speed, path length, and percent time spent in each quadrant of the pool during probe trials 
(analysis program WaterMaze3, Actimetrics, Evanston, IL, USA). All experimental procedures were performed blind to groups.

\section{Determination of $A \beta$ Levels}

Cortical $\mathrm{A} \beta 42$ and $\mathrm{A} \beta 40$ levels were measured by using a sensitive sandwich ELISA kit from Biosource (Camarillo, CA, USA). In brief, tissue was weighed and homogenized in 8 volumes of ice-cold guanidine buffer ( $5 \mathrm{M}$ guanidine $\mathrm{HCl}$ / $50 \mathrm{mM}$ Tris- $\mathrm{HCl} \mathrm{pH} \mathrm{8.0)} \mathrm{and} \mathrm{diluted} \mathrm{1:20.} \mathrm{The} \mathrm{homo-}$ genates were mixed overnight at room temperature and were diluted 1:50 in Dulbecco's phosphate-buffered saline containing 5\% BSA and $0.03 \%$ Tween-20 (DPBS-BSAT), followed by centrifugation at $16000 \mathrm{~g}$ for $20 \mathrm{~min}$ at $4^{\circ} \mathrm{C}$. The supernatant was diluted with standard diluent buffer supplemented with protease inhibitor cocktail (Complete Protease Inhibitor Cocktail, Roche Diagnostics, Mannheim, Germany) and $1 \mathrm{mM}$ PMSF. A total of $50 \mu \mathrm{l}$ were loaded onto ELISA plates in duplicate, and the manufacturer's instructions were followed. The $\mathrm{A} \beta$ standards were prepared in a buffer with the same composition of final tissue samples.

\section{Production of Protein Extracts}

For APP-derived fragments determination, cortical tissue was homogenized in a buffer containing SDS $2 \%$, Tris- $\mathrm{HCl}$ (10 mM, pH 7.4), protease inhibitors (1 mM PMSF and Complete Protease Inhibitor Cocktail, Roche Diagnostics) and phosphatase inhibitors $\left(0.1 \mathrm{mM} \mathrm{Na}_{3} \mathrm{VO}_{4}\right.$ and $1 \mathrm{mM}$ $\mathrm{NaF})$. The homogenates were sonicated for $2 \mathrm{~min}$ and centrifuged at $100000 \mathrm{~g}$ for $1 \mathrm{~h}$. Aliquots of the supernatant were frozen at $-80^{\circ} \mathrm{C}$ and protein concentration was determined by the Bradford method using the Bio-Rad protein assay (Bio-Rad, Hercules, CA, USA).

\section{Western Blotting}

For Western blot analysis of APP-derived fragments, aliquots of the protein extracts were mixed with XT sample buffer plus XT reducing agent (Bio-Rad) and boiled for $5 \mathrm{~min}$. Proteins were separated in a Criterion precast BisTris $4-12 \%$ gradient precast gel (Bio-Rad) and transferred to a PVDF membrane with $0.2 \mu \mathrm{m}$ removal rating (Hybond LFP, Amersham Biosciences, Little Chalfont, UK). The membranes were blocked with $5 \%$ milk, $0.05 \%$ Tween-20 in Tris-buffered saline (TBS) followed by overnight incubation with the following primary antibodies: mouse monoclonal 6E10 (amino acids $1-16$ of $\mathrm{A} \beta$ peptide, $1: 1000$, Covance, San Diego, CA, USA), rabbit polyclonal anti-APP C-terminal (amino acids 676-695) (1:2000, Sigma, St Louis, MO, USA) and mouse monoclonal anti- $\beta$-actin (1:100000, Sigma). After two washes in TBS/Tween20 and one wash in TBS alone, immunolabeled protein bands were detected by using HRP-conjugated anti-rabbit or anti-mouse antibody (1:5000, Dako, Denmark) following an enhanced chemiluminiscence system (ECL, Amersham Biosciences), and autoradiographic exposure to Hyperfilm ECL (Amersham Biosciences). Signals quantification was carried out using Quantity One v.4.6.3. software (Bio-Rad).

\section{Tissue Processing for Immunohistochemistry}

Under xylazine/ketamine anesthesia, animals were perfused transcardially with saline and $4 \%$ paraformaldehyde in phosphate buffer (PB). After perfusion, brains were removed, post-fixed in the same fixative solution for $1 \mathrm{~h}$ at room temperature and cryoprotected in $30 \%$ sucrose solution in $\mathrm{PB}$ overnight at $4{ }^{\circ} \mathrm{C}$. Microtome sections $(30-\mu \mathrm{m}$-thick) were cut coronally, collected free-floating and stored in $30 \%$ ethylene glycol, $30 \%$ glycerol, and $0.1 \mathrm{M} \mathrm{PB}$ at $-20^{\circ} \mathrm{C}$ until processed.

For immunofluorescence, five-six free-floating tissue sections of four animals per group were processed. Brain sections were washed $(3 \times 10 \mathrm{~min})$ with $\mathrm{PBS} 0.1 \mathrm{M}(\mathrm{pH} 7.4)$ and incubated in blocking solution (PBS containing $0.3 \%$ Triton X$100,0.1 \%$ BSA and $2 \%$ normal goat serum) for $2 \mathrm{~h}$ at room temperature. For 6E10 immunostaining, sections were incubated in $70 \%$ formic acid for $10 \mathrm{~min}$ to expose the epitope. Primary and secondary antibodies were diluted in the blocking solution. Sections were incubated with the primary antibody for $24 \mathrm{~h}$ at $4{ }^{\circ} \mathrm{C}$, washed with PBS and incubated with the secondary antibody for $2 \mathrm{~h}$ at room temperature, protected from light. The primary antibody used was mouse monoclonal $6 \mathrm{E} 10$ (amino acids $1-17$ of $\mathrm{A} \beta$ peptide, $1: 200$, Chemicon, Temecula, CA, USA). Secondary antibody used was Alexa Fluor 488 goat anti-mouse, highly crossadsorbed $(1: 200$, InvitrogenMolecular Probes, Eugene, OR, USA). For better visualization of nuclei, sections were rinsed $15 \mathrm{~s}$ in the DNA marker TOPRO3 (Invitrogen-Molecular Probes) working concentration $4 \mu \mathrm{M}$ in PBS, and then washed $2 \mathrm{~min}$ in PBS before mounting (Martin et al, 2005). Sections were mounted on super frost plus slides, air dried for $24 \mathrm{~h}$, rinsed in toluene $(2 \times 5 \mathrm{~min})$, and coverslipped with Immu-Mount (Thermo Scientific, Pittsburgh, PA, USA) mounting medium. To ensure comparable immunostaining, sections were processed together under identical conditions. For the assessment of non-specific primary immunostaining, some sections from each experimental group were incubated without the primary antibody; in this case no immunostaining was observed. Non-specific secondary immunostaining was also evaluated by incubating sections with primary and its non-respective secondary antibody; again, no immunostaining was observed. Fluorescence signals were detected with confocal microscope LSM 510 Meta (Carl Zeiss, Oberkochen, Germany).

For p-tau staining, slides were treated with methanol and $\mathrm{H}_{2} \mathrm{O}_{2}$ to inhibit endogenous peroxidase activity, followed by blocking with $3 \%$ milk in TBS. Sections were incubated overnight with primary antibody AT8 (1:50, Pierce, Woburn, MA, USA) or PHF1 (1:100, gift from Dr J Avila, CBM, Madrid, Spain) at $4^{\circ} \mathrm{C}$. After washing, sections were incubated sequentially with biotinylated goat anti-mouse secondary antibody (1:500, DakoCytomation, Glostrup, Denmark) for $2 \mathrm{~h}$, an $\mathrm{ABC}$ kit immunosassay detection systems (Vector, Burlingame, CA, USA) for $90 \mathrm{~min}$, and developed with a DAB (3,3'-diaminobenzidine) solution (Peroxidase substrate kit, Vector). Sections were then washed in water before dehydrating and mounting in DPX (BDH).

\section{Quantitative Real-Time PCR}

Total RNA was extracted from prefrontal cortex using Trizol (Sigma), and was reverse-transcribed into cDNA. Real-time quantitative PCR assays were performed in triplicate in the presence of SYBRgreen (Sigma) to detect 
the amplification products. Samples were analyzed simultaneously for $\beta$-actin as the internal control using an $\mathrm{ABI}$ Prism 7300 sequence detector (Applied Biosystems, Foster City, CA, USA). Data were analyzed using Sequence Detection software v. 3.0. (Applied Biosystems). Sequences for quantitative PCR primers are indicated in Table 1.

\section{Statistical Analysis}

Results, reported as means \pm SEM, were analyzed with the SPSS package for Windows, version 15.0 (SPSS, Chicago, IL, USA). One-way ANOVA, followed by Sheffé post-hoc test was used for behavioral data, and ANOVA followed by Tukey's hsd post-hoc test was used for quantitative PCR results. In experiments where two groups were compared, results were analyzed using Student's $t$-test.

\section{RESULTS}

\section{Rosiglitazone Treatment Ameliorates Memory Deficits in the Object Recognition and MWM Tests}

Transgenic J20 mice showed memory impairment at 10 months of age in the object recognition test, the discrimination index being significantly lower than in non-transgenic animals $(0.46 \pm 0.08$ vs $0.77 \pm 0.12)$. After 4 weeks of daily treatment, rosiglitazone reversed this deficit, and the discrimination index was similar to the non-transgenic group $(0.77 \pm 0.07)$ (Figure 1$)$.

At this age, mice also underwent the MWM. In this test, all experiments with transgenic animals and non-transgenic littermates were carried out on a blind basis. No significant differences among groups were found during the days of visible platform training (not shown) indicating absence of effects of transgene and/or rosiglitazone. In the spatial component of the test (invisible platform), the drug failed to improve spatial memory, escape latencies being higher than in non-transgenic mice (Figure 2a). In the probe trial, which provides a putative measure of memory retention, no improvement was either found (not shown).

The results in the MWM suggested that a 4-week treatment with rosiglitazone was not enough to restore the hippocampus function for an accurate performance. Drug treatment was then continued for 12 additional weeks. After that, animals underwent another MWM. Escape latencies of rosiglitazone-treated animals were then similar to those of non-transgenic mice in the invisible platform, and in both cases latencies were much lower than in saline-treated J20 mice (Figure $2 \mathrm{~b}$ ). It has been suggested that the sensitivity of the MWM test can be increased by giving shorter probe trials (Gerlai, 2001); we thereby analyzed the performance of mice during the first 15 and $60 \mathrm{~s}$ of every probe trial. In the probe trial, saline-treated transgenic mice spent a percent time in the target quadrant significantly lower than the drug-treated and the non-transgenic group (Figure 2c).

\section{Rosiglitazone Reduces Brain $A \beta$ Levels and $A \beta$ Plaque Deposition}

Cortical levels of $\mathrm{A} \beta 40$ and $\mathrm{A} \beta 42$ were determined in transgenic mice by ELISA after 16 weeks of rosiglitazone treatment. As shown in Figure $3 \mathrm{a}$, rosiglitazone decreased $\mathrm{A} \beta 42$ levels by $\sim 57 \%$ and also $\mathrm{A} \beta 40$ levels by $\sim 72 \%$.

Western blot analysis was carried out in cortical protein extracts from transgenic animals. Using 6E10 antibody, we detected in blots a band at $\sim 56 \mathrm{kDa}$, corresponding in size with the $\mathrm{A} \beta$ dodecamer, termed $\mathrm{A} \beta^{*} 56$, which correlates with cognitive deficits in transgenic mice (Lesne et al, 2006). Rosiglitazone decreased the intensity of this band by $\sim 36 \%$ (Figure 3b).

Amyloid plaques are already formed in hippocampal subfields of most J20 mice at 5-7 months of age and are

Table I Primers Used in this Work

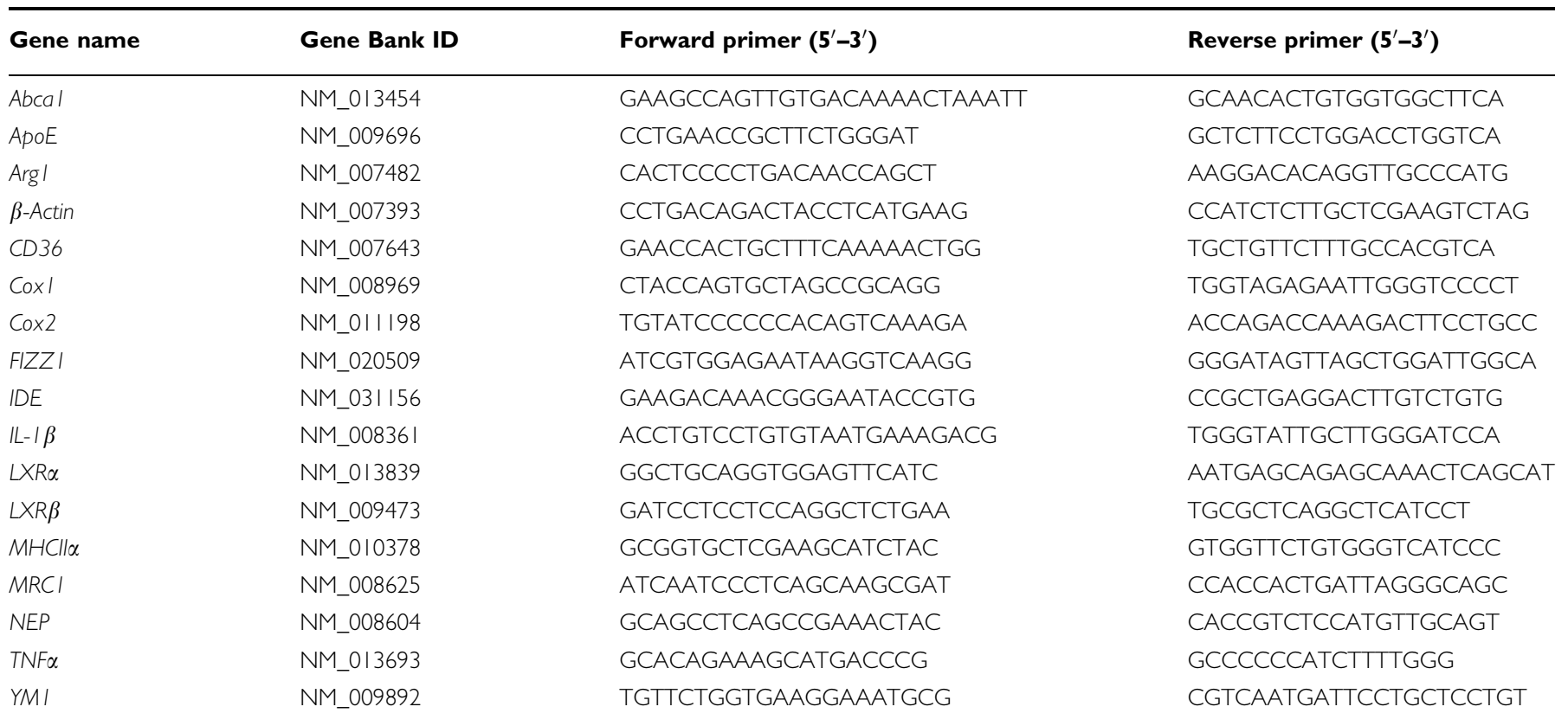

Abbreviations: IDE, insulin-degrading enzyme; LXR, liver $X$ receptors; NEP, neprilysin. 


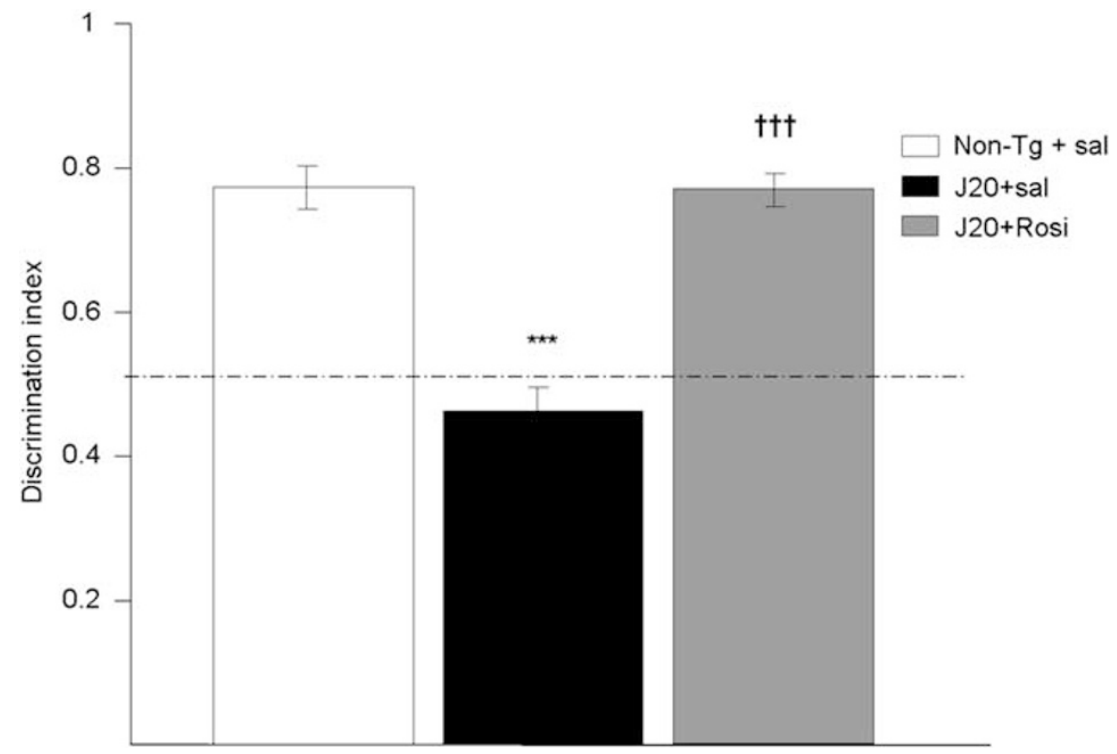

Figure I Reversal by daily treatment for 4 weeks with rosiglitazone (Rosi, $5 \mathrm{mg} / \mathrm{kg}$ p.o.) of the memory deficit shown by I0-month-old transgenic mice (J20 line) in the object recognition test. Values are means \pm SEM ( $n=1|-| 2$ animals per group). **** $<0.00 \mid$ vs non-transgenic (Non-Tg + sal) mice; ${ }^{\dagger \dagger} P<0.00$ I vs saline-treated transgenic mice (ANOVA followed by Scheffé's $t$-test).

abundant in all of them when they are 8-10 months old (Mucke et al, 2000). The animals used here, which were 9-months old at the beginning of the treatment, should therefore have numerous amyloid plaques in the hippocampus and cerebral cortex. Using 6E10 antibody, which recognizes the amino-terminal region of $\mathrm{A} \beta$, saline-treated animals showed a high number of these plaques in the three brain areas analyzed (prefrontal and entorhinal cortex, and hippocampus). In rosiglitazone-treated transgenic mice, plaques were virtually undetectable in the three studied regions (Figure 4).

Likewise, higher magnification of the hippocampal pyramidal cell layer (CA1) revealed that rosiglitazone lowered the levels of intracellular $\mathrm{A} \beta$ compared with saline-treated mice, suggesting that the drug may promote not only the degradation of amyloid plaques, but also the clearance of soluble intracellular A $\beta$ (Figure 4, insets).

\section{Effect of Rosiglitazone on APP Processing}

To determine whether rosiglitazone decreased $\mathrm{A} \beta$ levels by changing APP processing, we analyzed the levels of the APP-derived fragments by western blot, using the anti-APP C-terminal antibody. We found that the levels of total hAPP, the carboxy-terminal fragment (CTF) C83, and $\alpha$ APPs were slightly lower in rosiglitazone-treated than in saline-treated mice (Figure 5). As shown also in Figure 5, the levels of CTF C99, precursor of the $\mathrm{A} \beta$ peptide, did not change, suggesting that rosiglitazone did not reduce $\mathrm{A} \beta$ production by changing the amyloidogenic APP processing.

\section{Rosiglitazone Reduces p-Tau Aggregates}

We also analyzed in transgenic mice another pathological hallmark of $\mathrm{AD}$, the presence of neuropil threads containing phosphorylated tau. To this end, we carried out immunohistochemical studies in brain slices using AT8 and PHF1 antibodies, which recognize different forms of phosphorylated tau. Although tau pathology has not been explicitly described in these animals, we observed AT8 and PHF1 signals, probably corresponding to the presence of dystrophic neurites (Figure 6a and b). It should be noted that PHF1 signals were also observed in a different line of APP transgenic mice without other overt signs of tau pathology (Cancino et al, 2008). Saline-treated transgenic J20 mice showed p-tau-positive neuropil threads in the hippocampus using the AT8 antibody (Figure 6a). These mice also showed neuropil threads in the same region using the PHF1 antibody, but staining was less pronounced (Figure 6b). Non-transgenic mice did not show any p-tau staining (Figure $6 a$ and $b$ ). Rosiglitazone clearly decreased the number of p-tau aggregates in transgenic mice (Figure $6 \mathrm{c}$ ).

\section{Effects of Rosiglitazone on A $\beta$ Degradation}

By using quantitative PCR, we first analyzed the expression of the two main $A \beta$-degrading enzymes, NEP, and IDE. The expression of both enzymes did not change in any experimental group (Figure 7a).

Recently, it has been described that ApoE facilitates the proteolytic clearance of soluble $\mathrm{A} \beta$ from the brain within microglia by NEP and extracellularly by IDE. The ability of ApoE to promote $A \beta$ degradation is dependent upon the ApoE isoform and its lipidation status (Jiang et al, 2008). Accordingly, we studied the expression of ApoE, Abca1, and LXRs. ApoE expression was decreased in the two groups of transgenic mice compared with the non-transgenic group (Figure $7 \mathrm{~b}$ ). Rosiglitazone did not modify the expression of ApoE, but increased the expression of Abcal (Figure 7b), independent of expression changes in LXRs (data not shown). These results suggest that the drug may increase the lipidation of ApoE through an overexpression of Abcal.

\section{Rosiglitazone Switches on the Activated Microglial Phenotype}

Microglial activation is an important pathogenic component of neurodegenerative diseases and also one of the major 

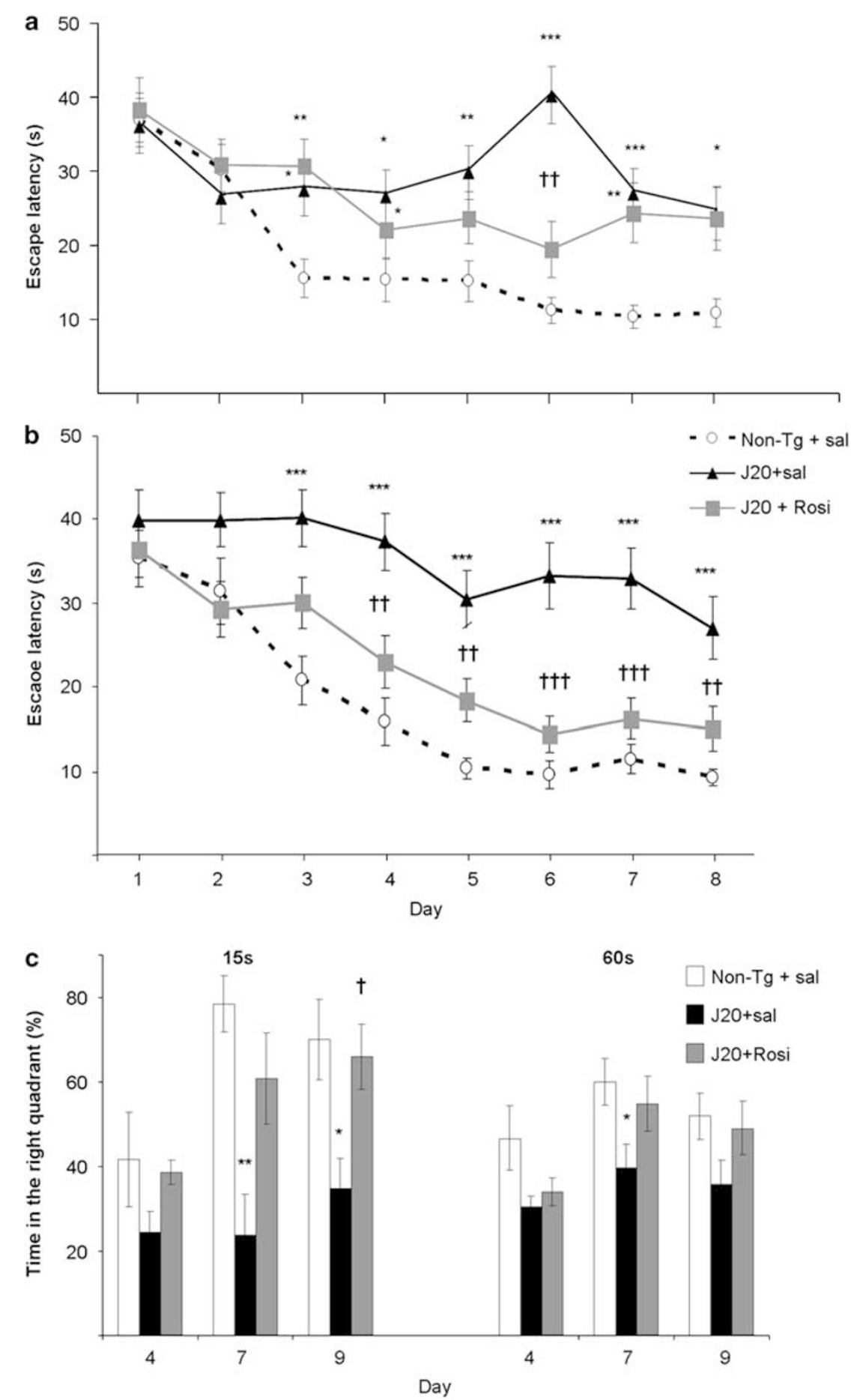

Figure 2 Effect of daily treatment with rosiglitazone (Rosi, $5 \mathrm{mg} / \mathrm{kg}$ p.o.) for 4 weeks or 4 months on performance of 120 mice in the Morris water maze. (a) Escape latency in the invisible-platform training after 4 weeks of daily treatment. Both groups of transgenic mice showed significantly longer escape latencies in the invisible-platform training when compared with the non-transgenic (Non-Tg) littermate controls. (b) After 4 months of treatment, rosiglitazone ameliorated spatial memory in transgenic mice; escape latencies in the invisible-platform training were not different from those of non-transgenic mice. (c) Percentage time spent in the right quadrant during the 15 and 60 s probe trials after 4 months of treatment. Saline-treated $J 20$ mice performed significantly worse than rosiglitazone-treated or Non-Tg littermate controls in the three 15 - and 60 -s probe trials. Values are means \pm SEM ( $n=1 \mid-12$ animals per group). * $P<0.05$, ${ }^{*} * P<0.0$ I, ${ }^{* * *} * P<0.001$ vs Non-Tg + sal, ${ }^{\dagger} P<0.0$ I, ${ }^{\dagger \dagger} P<0.0$ I, ${ }^{\dagger \dagger} P<0.00$ I vs $J 20+$ sal (ANOVA followed by Scheffé's $t$-test).

mechanisms of amyloid clearance. To elucidate whether rosiglitazone could modify microglial activation, we examined its phenotype by immunochemistry using the CD11b antibody, and the expression of proinflammatory factors.
As shown in Figure 8a, non-transgenic mice displayed a resting morphology, whereas saline-treated J20 mice displayed an activated microglia with an amoeboid morphology characteristic of a classic cytotoxic phenotype 
(Figure 8a), along with the overexpression of proinflammatory factors such as TNF $\alpha$ and Cox2 (Figure 8b). Rosiglitazone-treated transgenic mice displayed a different
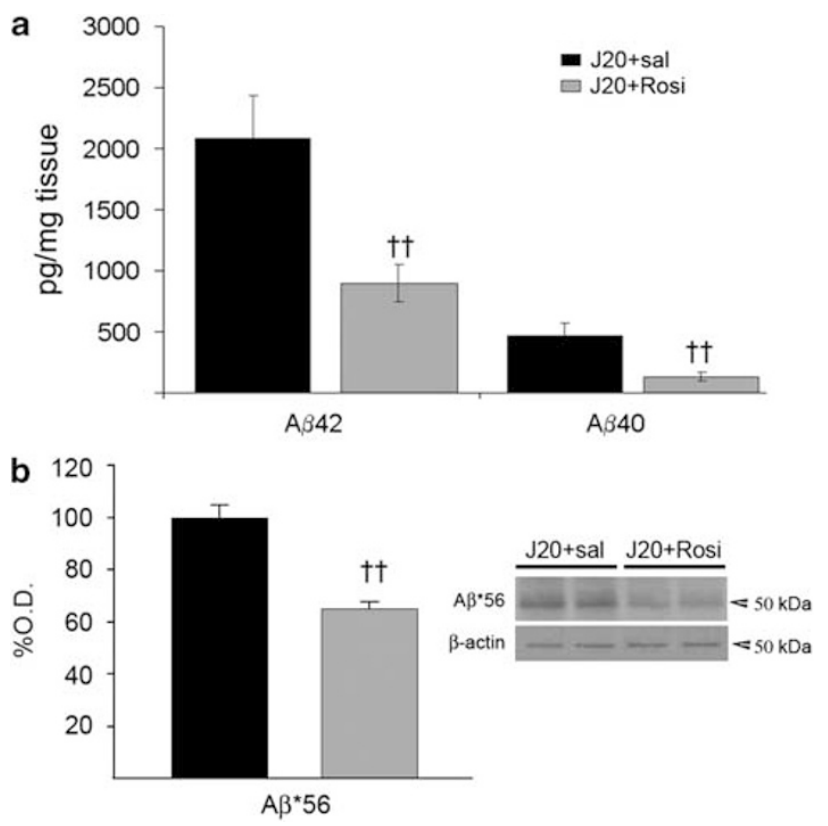

Figure 3 Daily treatment with rosiglitazone for 4 months markedly reduced $\beta$-amyloid $(A \beta)$ levels. (a) Levels of $A \beta 42$ and $A \beta 40$, determined by ELISA in cortical tissue, were decreased by $\sim 55$ and $\sim 70 \%$, respectively, after chronic treatment with the drug in transgenic $\mathrm{J} 20$ mice. (b) Rosiglitazone also reduced the levels of the $A \beta$ dodecamer, $A \beta * 56$, quantified by Western blot. Values are means $\pm \operatorname{SEM}(n=7-8$ animals per group). ${ }^{\dagger \dagger} P<0.0$ I vs $J 20+$ sal (Student's $t$-test). morphology (Figure 8a), similar to the resting phenotype, accompanied by a reduction in the expression of proinflammatory factors, and an induction of YM-1 and FIZZ-1 (Figure $8 \mathrm{~b}$ ), considered a marker of alternative differentiation in peripheral macrophages (Edwards et al, 2006). These animals also showed an increased expression of CD36 (Figure 9), a receptor that internalizes $\mathrm{A} \beta$ inside microglia increasing the $\mathrm{A} \beta$ phagocytic capabilities.

\section{DISCUSSION}

In this study, we report that rosiglitazone, a high-affinity agonist at $\operatorname{PPAR} \gamma$, promotes $\mathrm{A} \beta$ clearance, not only decreasing $\mathrm{A} \beta$ burden in the brain but, of particular interest, eliminating also the abundant amyloid plaques in the hippocampus and entorhinal cortex of Alzheimer's transgenic mice overexpressing mutant APP. Rosiglitazone switched on the activated microglial phenotype, promoting its phagocytic capability, reducing the expression of proinflammatory factors and increasing those of alternative differentiation. The decreased amyloid pathology may account for the reduction of neuropil threads containing phosphorylated tau and for the rescue of impaired recognition and spatial memory in the transgenic mice.

After 4 weeks of treatment, object recognition performance but not spatial memory was improved in rosiglitazone-treated transgenic mice. It has been suggested that spatial memory requires a more complete hippocampal function than does recognition memory (Broadbent et al, 2004) so it seems that the 4-week treatment was enough to improve the function in different brain areas related to recognition memory but not in the hippocampus.
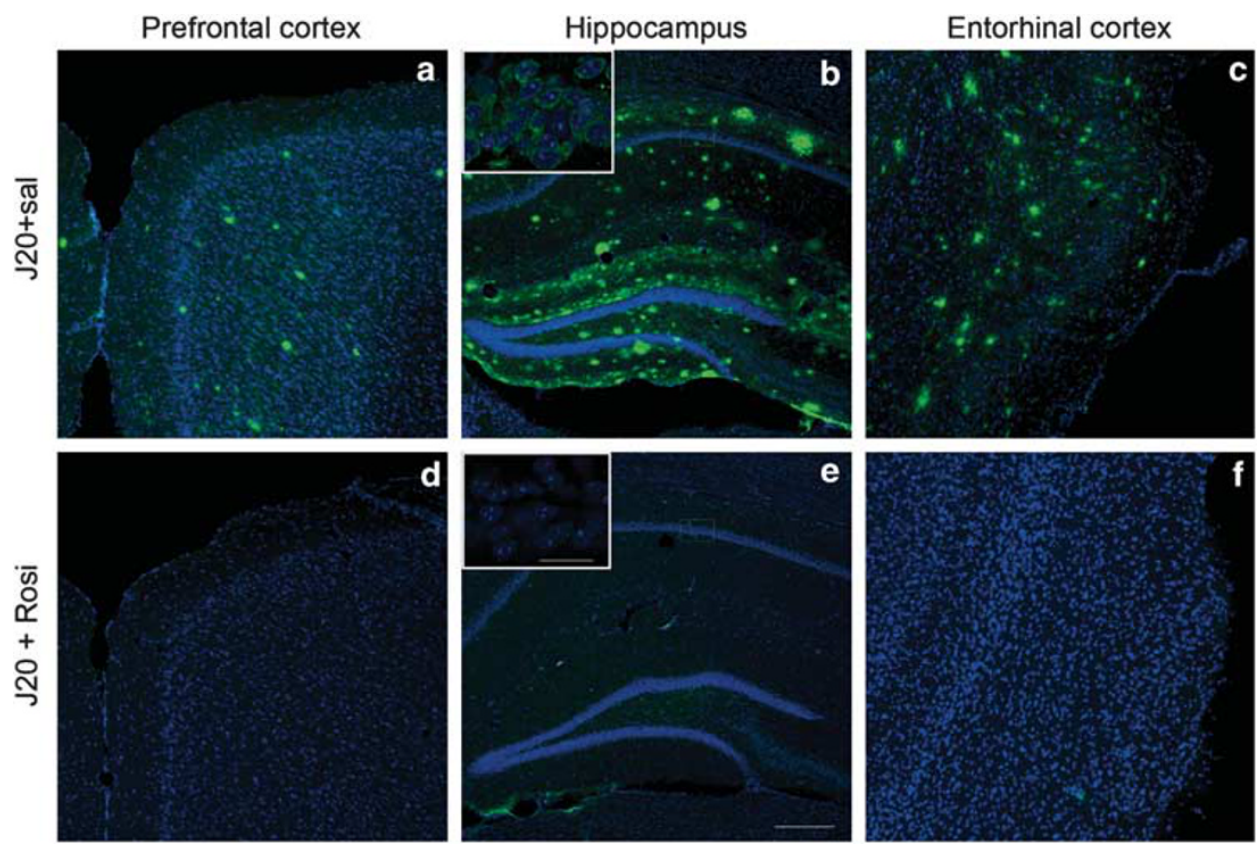

Figure 4 Representative images of the immunofluorescent staining in different brain regions for 6 EI0 antibody and the DNA marker TOPRO-3. (a-c) Multiple extracellular deposits of $\beta$-amyloid $(A \beta)$ amyloid peptide were detected in saline-treated $J 20$ mice. Rosiglitazone almost completely reduced staining of $A \beta$ deposits in the three areas studied: (d) prefrontal and (f) entorhinal cortex, and (e) hippocampus (scale bar $=100 \mu \mathrm{m}$ ). Small boxes in b and e are insets at higher magnification of hippocampal pyramidal cell layer CAI (scale bar $=10 \mu \mathrm{m}$ ), showing the reduction in the intracellular $A \beta$ labelling (Representative sections of $n=4$ animals per group). 

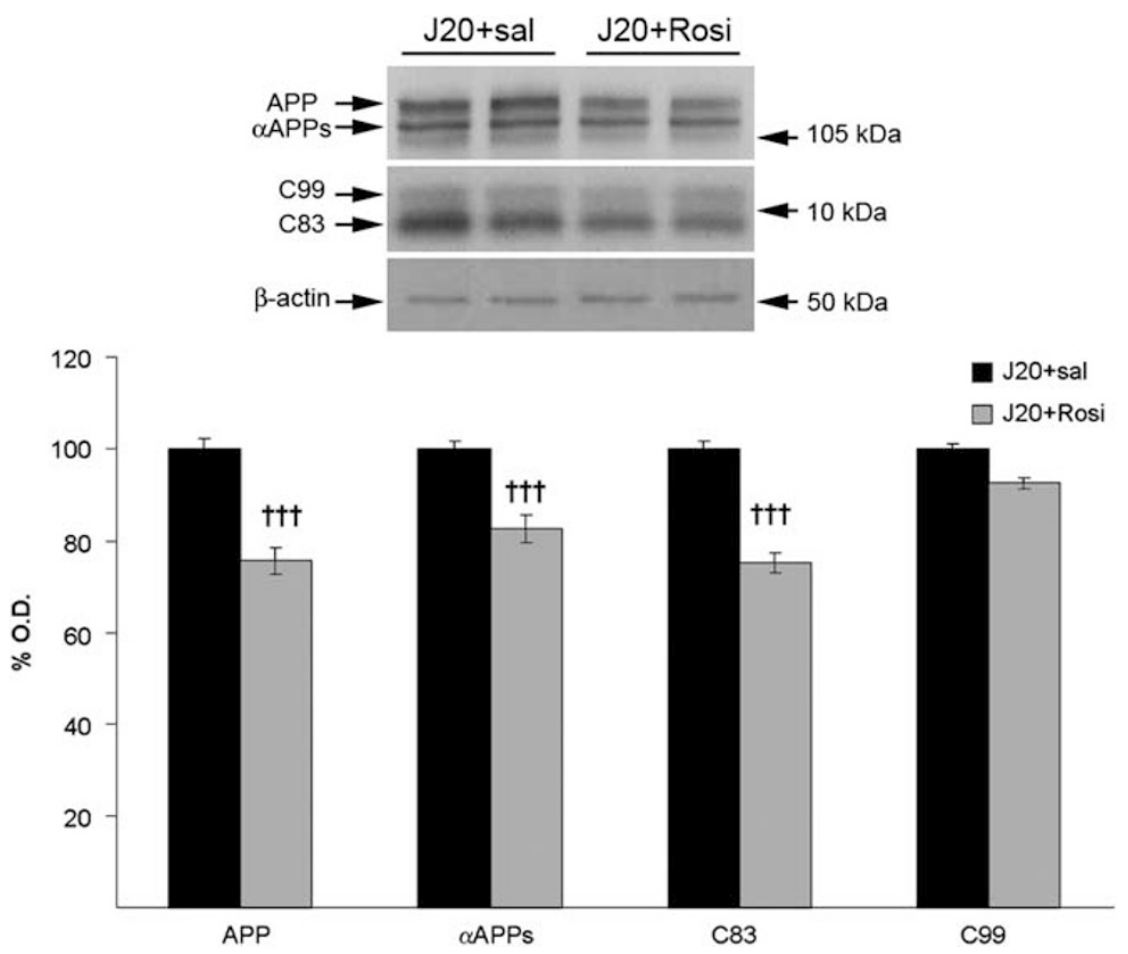

Figure 5 Effect of chronic treatment with rosiglitazone for 4 months on amyloid precursor protein (APP) processing. The drug decreased the levels of total APP, $\alpha$ APPs and the carboxy-terminal fragment (CTF) C83. However, the levels of the CTF C99, precursor of A $\beta$, were not affected. Values are means \pm SEM ( $n=7-8$ animals per group). ${ }^{\dagger \dagger} P<0.001$ vs $20+$ sal (Student's $t$-test).

A longer-lasting rosiglitazone treatment also rescued impaired spatial memory. These effects are probably of central origin as rosiglitazone passes readily into the brain (Strum et al, 2007). We and others have reported an attenuation of learning and memory deficits of APP transgenic mice in the radial maze and object recognition tests after chronic rosiglitazone administration (Pedersen et al, 2006; Escribano et al, 2009). However, it was also recently reported that, at variance with the present results, APP mice treated with pioglitazone for 2 months did not improve their spatial memory in the MWM (Nicolakakis et al, 2008). The difference of the latter study with this work may simply depend on the different PPAR $\gamma$ agonists used and also on the duration of the treatment.

The treatment for 4 months with rosiglitazone reduced the levels of $\mathrm{A} \beta$ by $50-70 \%$, eliminated almost completely the intraneuronal $\mathrm{A} \beta$, which has a major role in the pathogenesis of $\mathrm{AD}$ (Wirths et al, 2004), and also decreased the levels of the $\mathrm{A} \beta$ dodecamer, which seems to be directly related with the appearance of cognitive deficits (Lesne et al, 2006). It is interesting to note that amyloid plaques were virtually nonexistent in the hippocampus and areas of the cerebral cortex after the chronic treatment. The great reduction in amyloid pathology may account for the rescue of memory in these mice. In previous studies, controversial effects have been reported on the effect of treatment with PPAR $\gamma$ agonists on amyloid burden in AD mouse models. In keeping with our results, Toledo and Inestrosa (2010) recently reported that chronic rosiglitazone treatment of transgenic APP/PS1 mice reduced $\mathrm{A} \beta$ aggregates and $\mathrm{A} \beta$ oligomers and also restored spatial memory impairment induced by amyloid burden. In a study using Tg2576 mice it was found that rosiglitazone reduced by $\sim 25 \% \mathrm{~A} \beta 42$ levels without affecting $\mathrm{A} \beta 40$ levels or amyloid plaques (Pedersen et al, 2006). In the latter study, it was reported that rosiglitazone attenuated the reduction of IDE mRNA observed in Tg2576 mice in the hippocampus but not in the frontal cortex, wherein a decrease of $\mathrm{A} \beta 42$ but not of A $\beta 40$ levels was found (Pedersen et al, 2006). It should, however, be noted that IDE degrades to the same extent $\mathrm{A} \beta 40$ and $\mathrm{A} \beta 42$ (Vekrellis et al, 2000). On the other hand, it is unclear that increased NEP levels may be beneficial to amyloid pathology, as this enzyme neither degrades $\mathrm{A} \beta$ oligomers nor restores memory function in an AD mouse model (Meilandt et al, 2009).

In another study, where Tg2576 mice were treated with ibuprofen or pioglitazone, both drugs reduced $\mathrm{A} \beta 40$ levels, but $A \beta 42$ levels and the number of amyloid plaques only were decreased with ibuprofen (Yan et al, 2003). Conversely, the treatment with the same drugs of APPV717I mice did not modify $\mathrm{A} \beta 40$ levels, and $\mathrm{A} \beta 42$ levels and plaques only were reduced with pioglitazone (Heneka et al, 2005).

The striking amelioration of amyloid pathology here found could be because of a lower production of $\mathrm{A} \beta$. However, rosiglitazone did not modify the levels of C99, precursor of the $\mathrm{A} \beta$ peptide, suggesting that this was not the main mechanism. Conversely, the treatment for 7 days with pioglitazone (target dose of $40 \mathrm{mg} / \mathrm{kg}$ ) reduced C99 levels in APP mice with the London mutation, an effect accompanied by a decrease in BACE1 gene transcription (Heneka et al, 2005; Sastre et al, 2006). Not only the different drug and schedule of treatment but also the different line of transgenic mice in which $\beta$ - and $\gamma$-secretase processing are not favored to the same extent may account for the difference (Van Dam and De Deyn, 2006). It is of note that 
a Non-Tg+sal

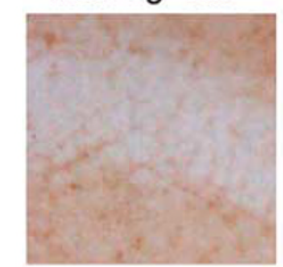

b

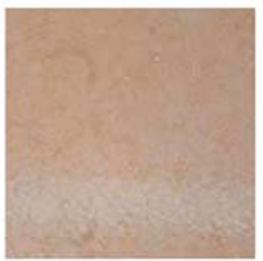

c

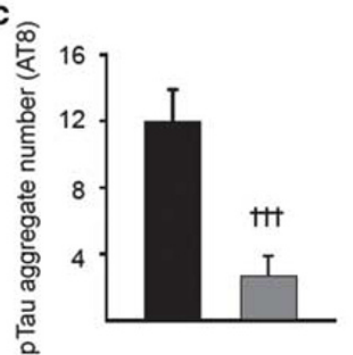

J20+sal
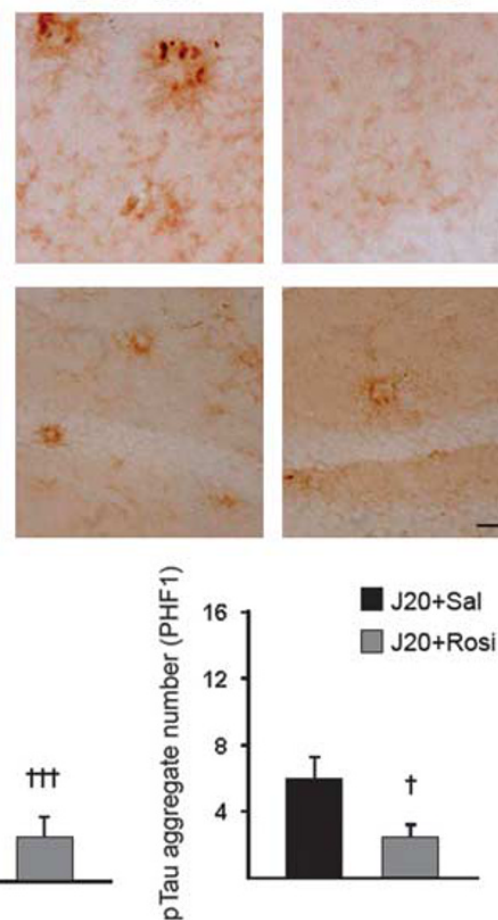

J20+Rosi
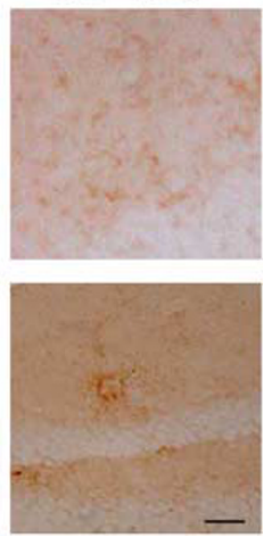

$20+$ Sal

$20+$ Rosi
Figure 6 Chronic rosiglitazone treatment for 4 months reduced phosphorylated tau in transgenic mice (|20 line). (a) Representative images of p-tau aggregates in the hippocampus using the AT8 antibody. No p-tau staining was observed in non-transgenic (Non-Tg) mice. Numerous aggregates were observed in saline-treated transgenic mice and a marked reduction was found after Rosiglitazone treatment. (b) Representative images of p-tau aggregates in the hippocampus using the PHFI antibody. The results obtained were similar to those depicted in a. (Scale bar $=25 \mu \mathrm{m}$ ). (c) Number of p-tau aggregates using AT8 or PHFI antibody. Quantitative data are means \pm SEM ( $n=4$ animals per group). ${ }^{\dagger} P<0.05,{ }^{\dagger \dagger} P<0.00$ I vs $J 20+$ sal (Student's $t$-test).

in vitro studies also showed distinct effects of $\operatorname{PPAR} \gamma$ overexpression/activation on BACE1 levels and activity, decrease or no change, in spite of a reduction in $\mathrm{A} \beta$ levels (Camacho et al, 2004; Sastre et al, 2006).

Dystrophic neurites are closely associated with amyloid deposits, and are correlated with $\mathrm{AD}$ dementia scores (Mckee et al, 1991; Selkoe, 1994). In this study, neuropil threads in J20 mice were clearly immunostained with antiphosphorylated tau antibodies (AT8 and PHF1), and rosiglitazone markedly reduced the immunostaining in parallel with the rescue of impaired recognition and spatial memory in the transgenic mice. Recently, it has been described that a reduction in tau expression prevents the cognitive deficit in mice overexpressing APP despite high levels of $\mathrm{A} \beta$, supporting the role of tau in the amyloid pathogenic cascade (Roberson et al, 2007). In accordance with our findings, the treatment with troglitazone, another thiazolidinedione, of cells expressing four-repeat tau, significantly reduced tau phosphorylation (D'abramo et al, 2006).

The observed reduction in amyloid and tau pathology after rosiglitazone could be because of an increase in the brain clearance ability. Indeed, a clearance mechanism for $\mathrm{A} \beta$ peptide after PPAR $\gamma$ activation was already described in neuronal and glial cultures (Camacho et al, 2004). Using

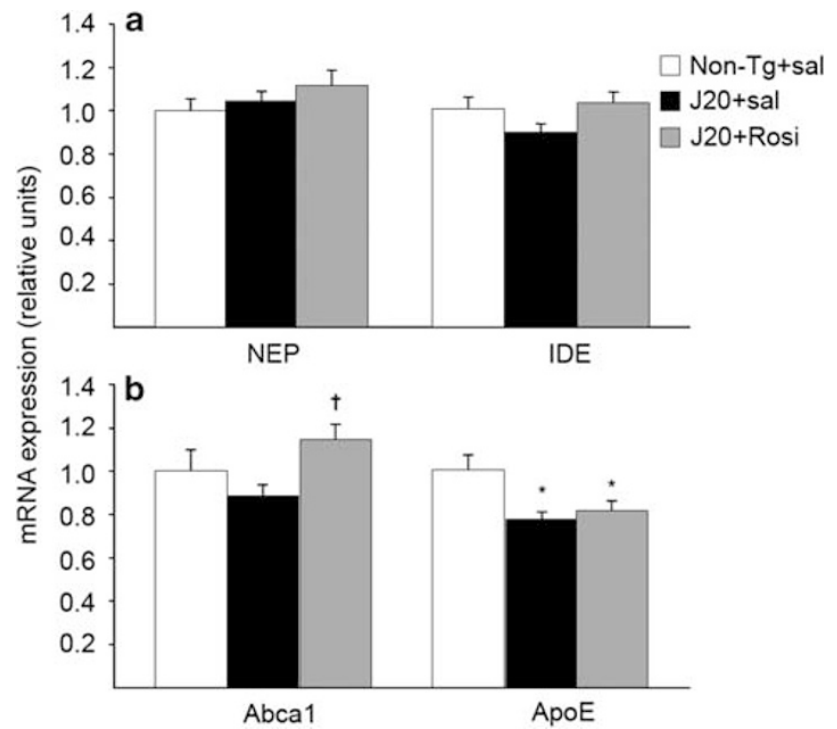

Figure 7 Effect of chronic rosiglitazone treatment on $\beta$ amyloid $(A \beta)$ degrading mechanisms. (a) The expression of the two main $A \beta$-degrading enzymes, neprilysin (NEP), and insulin-degrading enzyme (IDE) was similar in the three experimental groups. (b) Rosiglitazone increased the expression of the lipid-transporter Abcal, but not that of ApoE, which was decreased in the groups of transgenic 120 mice. Values are means \pm SEM ( $n=7-8$ animals per group). ${ }^{*} P<0.05$ vs non-transgenic $\left(\right.$ Non-Tg) + sal, ${ }^{\dagger} P<0.05$ vs $120+$ sal (ANOVA followed by Tukey's HSD post-hoc test).

quantitative PCR, we studied the expression of the two main proteolytic enzymes that degrade $\mathrm{A} \beta$, NEP, and IDE. However, the expression of both enzymes was not altered in any experimental group.

ApoE facilitates the proteolytic degradation of $A \beta$ by NEP and IDE, the degradation being enhanced when ApoE is lipidated (Jiang et al, 2008). Genetic loss of the lipid transporter Abcal impairs ApoE lipidation and promotes amyloid deposition in AD mouse models (Wahrle et al, 2008). Abcal catalyses the ATP-dependent transport of cholesterol and phospholipids from the plasma membrane to lipid-free apolipoproteins including ApoE. We found that rosiglitazone significantly increased the expression of Abcal in APP mice. This increase could lead to a more marked lipidation of ApoE in rosiglitazone-treated mice, facilitating $\mathrm{A} \beta$ degradation. In keeping with these data, increased expression of Abcal, without modifications in ApoE levels, appears to be sufficient for the reduction in $\mathrm{A} \beta$ levels in PDAPP transgenic mice (Wahrle et al, 2008). On the other hand, deficiency of LXRs, transcription factors that promote Abcal and ApoE expression, exacerbates AD pathology in vivo, whereas treatment of Alzheimer's mice with synthetic LXR agonists reduces amyloid load and improves cognitive performance (Fan et al, 2009). Here, we failed to observe changes in LXRs expression after rosiglitazone treatment. Nevertheless, it has been observed, using microarray and northern blot analyses, that PPAR $\gamma$ activation may directly increase the expression of Abcal (Hodgkinson and Ye, 2003). These results tend to support a role for ApoE in the effects of PPAR $\gamma$ agonists in AD patients. Indeed, rosiglitazone failed to improve cognition in patients with the ApoE $\varepsilon 4$ allele (Risner et al, 2006). 

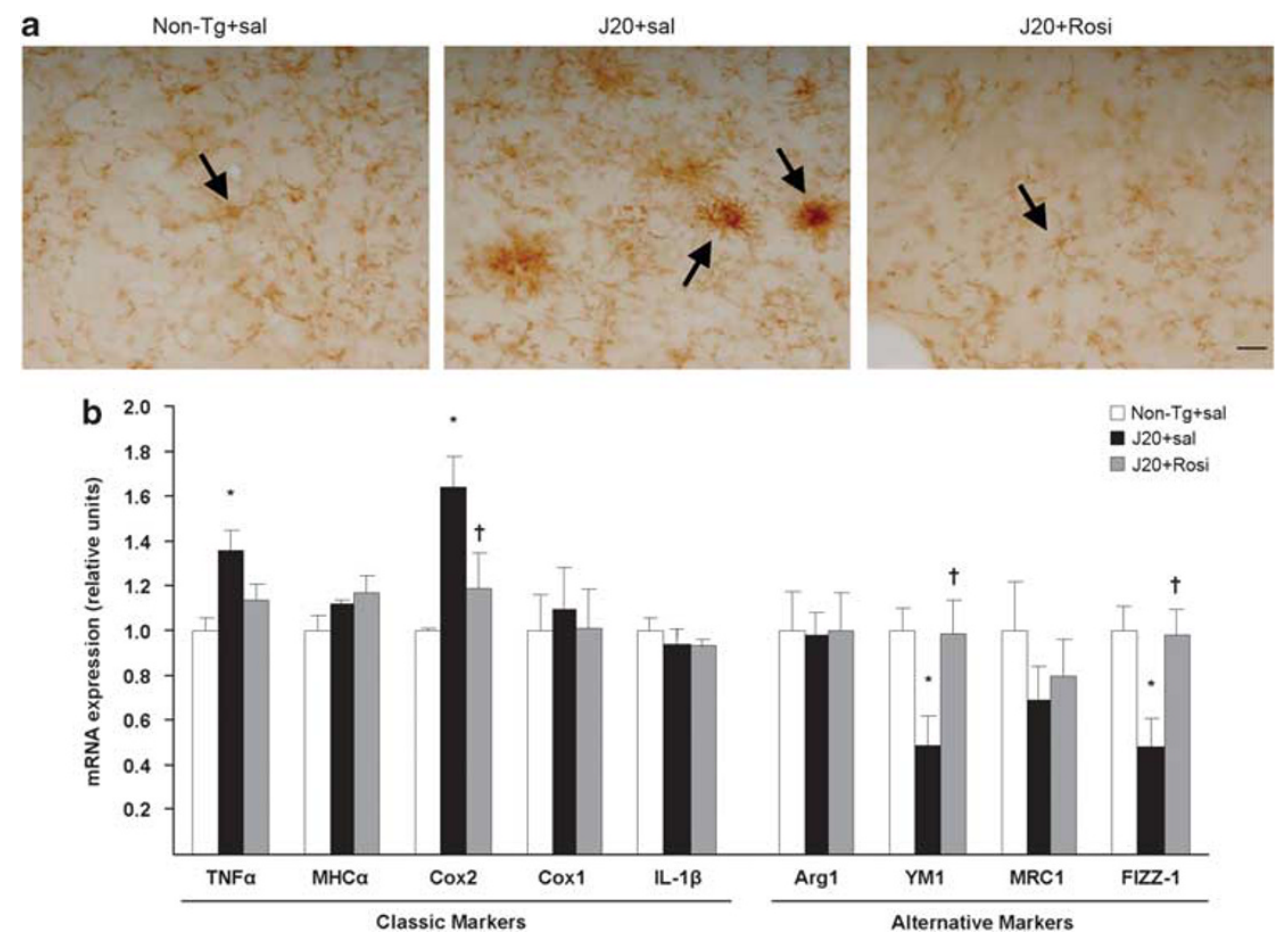

Figure 8 Modification by chronic rosiglitazone of the microglial phenotype in 120 transgenic mice. (a) Representative images of microglial immunolabelling using the CDIIb antibody showed an amoeboid morphology (arrow) in the saline-treated J20 mice. Both non-transgenic and rosiglitazone-treated transgenic mice showed a "resting"-like morphology (arrows). Scale bar $=20 \mu \mathrm{m}$. (b) Saline-treated 120 mice showed an overexpression of the proinflammatory factors Cox2 and TNF $\alpha$, which were significantly or partially reversed by the drug. Rosiglitazone prevented the reduced expression of the markers of alternative phenotype YMI and FIZZ-I observed in 120 mice. Values are means \pm SEM ( $n=7-8$ animals per group). * $P<0.05$ vs non-transgenic $($ Non- $T g)+$ sal, ${ }^{\dagger} P<0.05$, vs $J 20+$ sal (ANOVA followed by Tukey's HSD post-hoc test).

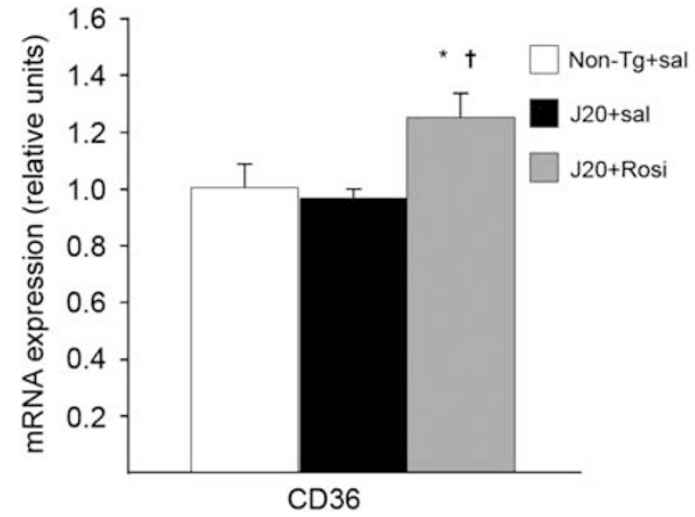

Figure 9 Chronic rosiglitazone treatment increased the expression of CD36 receptor. Values are means \pm SEM ( $n=7-8$ animals per group). ${ }^{*} P<0.05$ vs non-transgenic (Non-Tg) + sal, ${ }^{\dagger} P<0.05$ vs $220+$ sal (ANOVA followed by Tukey's HSD post-hoc test).

Despite the classical hypothesis of the cytotoxic features of activated microglia, recent evidences suggest that microglia are protective in the early stages of $\mathrm{AD}$ by promoting amyloid phagocytosis and clearance of fibrillar and soluble amyloid. Microglia can be activated towards a classical proinflammatory phenotype, but also to a neuroprotective phenotype (Venneti et al, 2009). Early microglial activation has been attributed to a neuroprotective role in amyloid pathology, promoting $\mathrm{A} \beta$ clearance (Yan et al, 2003). Different receptors expressed in the microglia, such as CD36, are involved in this clearance process (Yan et al,
1996; El Khoury et al, 1998). Microglia cells also express enzymes such as IDE and NEP (Leissring et al, 2003), and participate in the ApoE-related $\mathrm{A} \beta$ degradation (Jiang et al, 2008). However, with the progression of the disease, the microglial neuroprotective property decrease and the proinflammatory characteristics become more prominent. Furthermore, a recent study has described that high levels of serum $\mathrm{TNF} \alpha$ are associated with an increase in cognitive decline in AD (Holmes et al, 2009). In this study, transgenic APP mice showed a microglial morphology characteristic of a classical proinflammatory phenotype, along with an overexpression of $\operatorname{TNF} \alpha$ and $\operatorname{Cox} 2$, which may contribute to the pathogenic events. Rosiglitazone-treated animals presented in turn a different microglial morphology, similar to resting microglia, but with a probably higher phagocytic activity because of the increased CD36 receptor expression. Accordingly, rosiglitazone-induced upregulation of CD36 promotes microglia-mediated phagocytosis in cell cultures (Zhao et al, 2009). This change in microglial morphology was accompanied by an induction in the expression of YM-1 and FIZZ-1, markers for alternative activation.

In conclusion, these results indicate that rosiglitazone reduces $\mathrm{AD}$ pathology and restores the hippocampal function, leading to a rescue of memory impairment in APP transgenic mice. Of particular interest was the virtual elimination of the abundant amyloid plaques in the hippocampus and entorhinal cortex of old mice. We hypothesize that this $\operatorname{PPAR} \gamma$ agonist could mediate the activation of a cell-dependent clearance mechanism, possibly by transcriptional activation of some proteins involved 
in the degradation of $\mathrm{A} \beta$ and tau. This study provides further mechanistic support for the use of rosiglitazone in the treatment of $\mathrm{AD}$.

\section{ACKNOWLEDGEMENTS}

This study was supported by the Spanish Ministry of Science (SAF2005-05086, SAF2008-02342), CIBERNED (Spain), and UTE project FIMA, Spain. We thank María Espelosín and Sergio María for technical help. We also thank Gobierno de La Rioja and CIMA for fellowships.

\section{DISCLOSURE}

The author(s) declare(s) that, except for income received from the primary employer, no financial support or compensation has been received from any individual or corporate entity over the past 3 years for research or professional service and there are no personal financial holdings that could be perceived as constituting a potential conflict of interest.

\section{REFERENCES}

ADAPT Research Group (2008). Cognitive function over time in the Alzheimer's Disease Anti-inflammatory Prevention Trial (ADAPT): results of a randomized, controlled trial of naproxen and celecoxib. Arch Neurology 65: 896-905.

Bayer TA, Wirths O, Majtenyi K, Hartmann T, Multhaup G, Beyreuther $\mathrm{K}$ et al (2001). Key factors in Alzheimer's disease: beta-amyloid precursor protein processing, metabolism and intraneuronal transport. Brain Pathol 11: 1-11.

Biessels GJ, Kappelle LJ (2005). Increased risk of Alzheimer's disease in Type II diabetes: insulin resistance of the brain or insulin-induced amyloid pathology? Biochem Soc Trans 33: 1041-1044.

Broadbent NJ, Squire LR, Clark RE (2004). Spatial memory, recognition memory, and the hippocampus. Proc Natl Acad Sci USA 101: 14515-14520.

Camacho IE, Serneels L, Spittaels K, Merchiers P, Dominguez D, De Strooper B (2004). Peroxisome-proliferator-activated receptor gamma induces a clearance mechanism for the amyloid-beta peptide. J Neurosci 24: 10908-10917.

Cancino GI, Toledo EM, Leal NR, Hernandez DE, Yevenes LF, Inestrosa NC et al (2008). STI571 prevents apoptosis, tau phosphorylation and behavioural impairments induced by Alzheimer's beta-amyloid deposits. Brain 131: 2425-2442.

d'Abramo C, Massone S, Zingg JM, Pizzuti A, Marambaud P, Dalla Piccola B et al (2005). Role of peroxisome proliferator-activated receptor gamma in amyloid precursor protein processing and amyloid beta-mediated cell death. Biochem J 391: 693-698.

d'Abramo C, Ricciarelli R, Pronzato MA, Davies P (2006). Troglitazone, a peroxisome proliferator-activated receptorgamma agonist, decreases tau phosphorylation in CHOtau4R cells. J Neurochem 98: 1068-1077.

Edwards JP, Zhang X, Frauwirth KA, Mosser DM (2006). Biochemical and functional characterization of three activated macrophage populations. J Leukoc Biol 80: 1298-1307.

El Khoury J, Hickman SE, Thomas CA, Loike JD, Silverstein SC (1998). Microglia, scavenger receptors, and the pathogenesis of Alzheimer's disease. Neurobiol Aging 19: S81-S84.

Escribano L, Simon AM, Perez-Mediavilla A, Salazar-Colocho P, Del Rio J, Frechilla D (2009). Rosiglitazone reverses memory decline and hippocampal glucocorticoid receptor down-regula- tion in an Alzheimer's disease mouse model. Biochem Biophys Res Commun 379: 406-410.

Fan J, Donkin J, Wellington C (2009). Greasing the wheels of Abeta clearance in Alzheimer's disease: the role of lipids and apolipoprotein E. Biofactors 35: 239-248.

Gerlai R (2001). Behavioral tests of hippocampal function: simple paradigms complex problems. Behav Brain Res 125: 269-277.

Hardy J, Selkoe DJ (2002). The amyloid hypothesis of Alzheimer's disease: progress and problems on the road to therapeutics. Science 297: 353-356.

Heneka MT, Sastre M, Dumitrescu-Ozimek L, Hanke A, Dewachter I, Kuiperi C et al (2005). Acute treatment with the PPARgamma agonist pioglitazone and ibuprofen reduces glial inflammation and Abeta1-42 levels in APPV717I transgenic mice. Brain 128: 1442-1453.

Hodgkinson CP, Ye S (2003). Microarray analysis of peroxisome proliferator-activated receptor-gamma induced changes in gene expression in macrophages. Biochem Biophys Res Commun 308: 505-510.

Holmes C, Cunningham C, Zotova E, Woolford J, Dean C, Kerr S et al (2009). Systemic inflammation and disease progression in Alzheimer disease. Neurology 73: 768-774.

in t' Veld BA, Ruitenberg A, Hofman A, Launer LJ, van Duijn CM, Stijnen T et al (2001). Nonsteroidal antiinflammatory drugs and the risk of Alzheimer's disease. N Engl J Med 345: 1515-1521.

Iwata N, Tsubuki S, Takaki Y, Watanabe K, Sekiguchi M, Hosoki E et al (2000). Identification of the major Abeta1-42-degrading catabolic pathway in brain parenchyma: suppression leads to biochemical and pathological deposition. Nat Med 6: 143-150.

Jiang Q, Lee CY, Mandrekar S, Wilkinson B, Cramer P, Zelcer N et al (2008). ApoE promotes the proteolytic degradation of Abeta. Neuron 58: 681-693.

Kurochkin IV, Goto S (1994). Alzheimer's beta-amyloid peptide specifically interacts with and is degraded by insulin degrading enzyme. FEBS Lett 345: 33-37.

Landreth GE, Heneka MT (2001). Anti-inflammatory actions of peroxisome proliferator-activated receptor gamma agonists in Alzheimer's disease. Neurobiol Aging 22: 937-944.

Lehmann JM, Lenhard JM, Oliver BB, Ringold GM, Kliewer SA (1997). Peroxisome proliferator-activated receptors alpha and gamma are activated by indomethacin and other non-steroidal anti-inflammatory drugs. J Biol Chem 272: 3406-3410.

Lehmann JM, Moore LB, Smith-Oliver TA, Wilkison WO, Willson TM, Kliewer SA (1995). An antidiabetic thiazolidinedione is a high affinity ligand for peroxisome proliferator-activated receptor gamma (PPAR gamma). J Biol Chem 270: 12953-12956.

Leissring MA, Farris W, Chang AY, Walsh DM, Wu X, Sun X et al (2003). Enhanced proteolysis of beta-amyloid in APP transgenic mice prevents plaque formation, secondary pathology, and premature death. Neuron 40: 1087-1093.

Lesne S, Koh MT, Kotilinek L, Kayed R, Glabe CG, Yang A et al (2006). A specific amyloid-beta protein assembly in the brain impairs memory. Nature 440: 352-357.

Martin RM, Leonhardt H, Cardoso MC (2005). DNA labeling in living cells. Cytometry A 67: 45-52.

McKee AC, Kosik KS, Kowall NW (1991). Neuritic pathology and dementia in Alzheimer's disease. Ann Neurol 30: 156-165.

Meilandt WJ, Cisse M, Ho K, Wu T, Esposito LA, Scearce-Levie K et al (2009). Neprilysin overexpression inhibits plaque formation but fails to reduce pathogenic Abeta oligomers and associated cognitive deficits in human amyloid precursor protein transgenic mice. J Neurosci 29: 1977-1986.

Mucke L, Masliah E, Yu GQ, Mallory M, Rockenstein EM, Tatsuno G et al (2000). High-level neuronal expression of abeta 1-42 in wildtype human amyloid protein precursor transgenic mice: synaptotoxicity without plaque formation. J Neurosci 20: 4050-4058.

Nicolakakis N, Aboulkassim T, Ongali B, Lecrux C, Fernandes P, Rosa-Neto P et al (2008). Complete rescue of cerebrovascular 
function in aged Alzheimer's disease transgenic mice by antioxidants and pioglitazone, a peroxisome proliferator-activated receptor gamma agonist. J Neurosci 28: 9287-9296.

Pedersen WA, McMillan PJ, Kulstad JJ, Leverenz JB, Craft S, Haynatzki GR (2006). Rosiglitazone attenuates learning and memory deficits in Tg2576 Alzheimer mice. Exp Neurol 199: 265-273.

Risner ME, Saunders AM, Altman JF, Ormandy GC, Craft S, Foley IM et al (2006). Efficacy of rosiglitazone in a genetically defined population with mild-to-moderate Alzheimer's disease. Pharmacogenomics J 6: 246-254.

Roberson ED, Scearce-Levie K, Palop JJ, Yan F, Cheng IH, Wu T et al (2007). Reducing endogenous tau ameliorates amyloid betainduced deficits in an Alzheimer's disease mouse model. Science 316: $750-754$.

Sastre M, Dewachter I, Rossner S, Bogdanovic N, Rosen E, Borghgraef $\mathrm{P}$ et al (2006). Nonsteroidal anti-inflammatory drugs repress beta-secretase gene promoter activity by the activation of PPARgamma. Proc Natl Acad Sci USA 103: 443-448.

Schiapparelli L, Simon AM, Del Rio J, Frechilla D (2006). Opposing effects of AMPA and 5-HT1A receptor blockade on passive avoidance and object recognition performance: correlation with AMPA receptor subunit expression in rat hippocampus. Neuropharmacology 50: 897-907.

Selkoe DJ (1994). Alzheimer's disease: a central role for amyloid. J Neuropathol Exp Neurol 53: 438-447.

Selkoe DJ (2001). Alzheimer's disease results from the cerebral accumulation and cytotoxicity of amyloid beta-protein. J Alzheimers Dis 3: 75-80.

Simard AR, Soulet D, Gowing G, Julien JP, Rivest S (2006). Bone marrow-derived microglia play a critical role in restricting senile plaque formation in Alzheimer's disease. Neuron 49: 489-502.

Strum JC, Shehee R, Virley D, Richardson J, Mattie M, Selley P et al (2007). Rosiglitazone induces mitochondrial biogenesis in mouse brain. J Alzheimers Dis 11: 45-51.

Su JH, Cummings BJ, Cotman CW (1998). Plaque biogenesis in brain aging and Alzheimer's disease. II. Progressive transformation and developmental sequence of dystrophic neurites. Acta Neuropathol 96: 463-471.

Sundararajan S, Jiang Q, Heneka M, Landreth G (2006). PPARgamma as a therapeutic target in central nervous system diseases. Neurochem Int 49: 136-144.

Tanzi RE, Moir RD, Wagner SL (2004). Clearance of Alzheimer's Abeta peptide: the many roads to perdition. Neuron 43: 605-608.
Toledo EM, Inestrosa NC (2010). Activation of Wnt signaling by lithium and rosiglitazone reduced spatial memory impairment and neurodegeneration in brains of an APPswe/PSEN1 $\triangle \mathrm{E} 9$ mouse model of Alzheimer's disease. Mol Psychiatry 15: 272-285.

Van Dam D, De Deyn PP (2006). Drug discovery in dementia: the role of rodent models. Nat Rev Drug Discov 5: 956-970.

Vekrellis K, Ye Z, Qiu W Q, Walsh D, Hartley D, Chesneau V et al (2000). Neurons regulate extracellular levels of amyloid betaprotein via proteolysis by insulin-degrading enzyme. J Neurosci 20: 1657-1665.

Venneti S, Wiley CA, Kofler J (2009). Imaging microglial activation during neuroinflammation and Alzheimer's disease. J Neuroimmune Pharmacol 4: 227-243.

Wahrle SE, Jiang H, Parsadanian M, Kim J, Li A, Knoten A et al (2008). Overexpression of ABCA1 reduces amyloid deposition in the PDAPP mouse model of Alzheimer disease. J Clin Invest 118: $671-682$.

Watson GS, Cholerton BA, Reger MA, Baker LD, Plymate SR, Asthana $S$ et al (2005). Preserved cognition in patients with early Alzheimer disease and amnestic mild cognitive impairment during treatment with rosiglitazone: a preliminary study. Am J Geriatr Psychiatry 13: 950-958.

Westerman MA, Cooper-Blacketer D, Mariash A, Kotilinek L, Kawarabayashi T, Younkin LH et al (2002). The relationship between Abeta and memory in the Tg2576 mouse model of Alzheimer's disease. J Neurosci 22: 1858-1867.

Wirths O, Multhaup G, Bayer TA (2004). A modified beta-amyloid hypothesis: intraneuronal accumulation of the beta-amyloid peptide-the first step of a fatal cascade. J Neurochem 91: 513-520.

Yan SD, Chen X, Fu J, Chen M, Zhu H, Roher A et al (1996). RAGE and amyloid-beta peptide neurotoxicity in Alzheimer's disease. Nature 382: 685-691.

Yan Q, Zhang J, Liu H, Babu-Khan S, Vassar R, Biere AL et al (2003). Anti-inflammatory drug therapy alters beta-amyloid processing and deposition in an animal model of Alzheimer's disease. J Neurosci 23: 7504-7509.

Zhao X, Grotta J, Gonzales N, Aronowski J (2009). Hematoma resolution as a therapeutic target: the role of microglia/ macrophages. Stroke 40: S92-S94.

Zipp F, Aktas O (2006). The brain as a target of inflammation: common pathways link inflammatory and neurodegenerative diseases. Trends Neurosci 29: 518-527. 